\title{
KORELASI ANTARA GAYA BELAJAR DAN MOTIVASI BELAJAR SISWA KELAS IV SD GUGUS UBUD KECAMATAN UBUD TAHUN PELAJARAN 2017/2018
}

\author{
Anak Agung Inten Mahayanti ${ }^{1}$, DB. Kt. Ngr. Semara Putra ${ }^{2}$, Ni Nyoman Ganing ${ }^{3}$ \\ $1,2,3$ Jurusan Pendidikan Guru Sekolah Dasar,Universitas Pendidikan Ganesha \\ Singaraja \\ Email : intenmahayanti29@gmail.com ${ }^{1}$, semara.putra@undiksha.ac.id, nyomanganing@yahoo.co.id
}

\begin{abstract}
Abstrak
Penelitian ini bertujuan untuk mengetahui korelasi yang signifikan antara gaya belajar dan motivasi belajar siswa kelas IV SD Gugus Ubud Kecamatan Ubud Tahun Pelajaran 2017/2018. Jenis penelitian ini adalah penelitian ex post facto, bersifat korelasional dengan teknik korelasi product moment dan regresi linear ganda. Populasi penelitian ini adalah seluruh siswa kelas IV SD Gugus Ubud tahun pelajaran 2017/2018 yang berjumlah 205 orang siswa. Penentuan sampel menggunakan teknik proportional random sampling. Sampel yang digunakan yaitu 150 orang siswa. Data penelitian dikumpulkan menggunakan teknik nontes yaitu dengan instrumen dalam bentuk angket gaya belajar dan motivasi belajar. Data hasil penelitian dianalisis menggunakan metode analisis statistik deskriptif dan metode analisis statistik inferensial dengan teknik analisis korelasi product moment dan regresi linear ganda dimana uji prasyaratnya yaitu uji normalitas, uji linearitas dan uji multikolinearitas. Hasil analisis diperoleh bahwa (1) terdapat korelasi yang signifikan antara gaya belajar visual dan motivasi belajar, dengan $r_{1}$ y sebesar 0,277 dan $r_{y 1.23}$ sebesar 0,214 lebih besar dari $r_{\text {tabe }} 5 \%=0,159$ serta sumbangan efektif sebesar $4,9 \%$, (2) terdapat korelasi yang signifikan antara gaya belajar auditori dan motivasi belajar, dengan $\mathrm{rx}_{2} \mathrm{y}$ sebesar 0,556 dan $\mathrm{r}_{\mathrm{y} 2.13}$ sebesar 0,509 serta sumbangan efektif sebesar $27,4 \%$, (3) terdapat korelasi yang signifikan antara gaya belajar kinestetik dan motivasi belajar, dengan $\mathrm{rx}_{3} \mathrm{y}$ sebesar 0,253 dan $r_{y 3.12}$ sebesar 0,168 serta sumbangan efektif sebesar $3,5 \%$, (4) secara bersama-sama terdapat korelasi yang signifikan gaya belajar visual, auditori dan kinestetik dengan motivasi belajar siswa kelas IV SD Gugus Ubud Kecamatan Ubud Tahun Pelajaran 2017/2018, dengan F $_{\text {hitung }}$ sebesar 27,186 lebih besar dari $F_{\text {tabel }}$ sebesar 2,68 serta sumbangan efektif sebesar $35,8 \%$.
\end{abstract}

Kata kunci :gaya belajar dan motivasi belajar

\begin{abstract}
The research was aimed at determining the significant correlation between learning style and learning motivation of the fourth-grade students in Gugus Ubud Elementary School Ubud Sub-district in the academic year 2017/2018. The study used ex-post facto research by using Product Moment correlation technique and multiple-linear regression. The population of this research was all students in the fourth-grade of Gugus Ubud in the academic year 2017/2018 consisting of 205 students. The samples were obtained using proportional random sampling so that 150 students were chosen in this research. The data were collected using non-test method which used the questionnaire of learning style and learning motivation as the instrument. The result of the research was analyzed using descriptive statistic analysis and inferential statistic analysis research by using product moment correlation technique and multiple-linear regression in which the prerequisite tests were normality test, linearity test, and multicollinearity test. The analysis shows that: (1) there is the significant correlation between visual learning style and learning motivation in which $r x_{1} y=0,277$ and $r_{y 1.23}=0,214, r_{\text {table }} 5 \%=0,159$ as well as effective contribution $=4,9 \%$, (2) there is the significant correlation between the auditory learning style and learning motivation in which $r x_{2} y=0,556$ and $r y_{2.13}=0,509$ as well as the effective contribution = $27,4 \%$, (3) there is the significant correlation between the kinesthetic learning style and learning motivation in which $r x_{3} y=0,253$ and $r y_{3.12}=0,168$ as well as the effective contribution $=3,5 \%$, (4) simultaneously, there is the significant correlation between the visual, auditory, and kinesthetic learning style and the learning motivation of the four-grade students of in Gugus Ubud Elementary School Ubud Sub-district in the academic year 2017/2018 in which $F_{\text {count }}=27,186>F_{\text {table }}=2,68$ as well as the effective contribution $=35,8 \%$.
\end{abstract}

Keyword : learning style and learning motivation 


\section{Pendahuluan}

Guru adalah tenaga kependidikan yang bertugas untuk mengembangkan segala potensipotensi yang dimiliki oleh siswa agar berkembang secara optimal kearah yang lebih baik. Dalam UU No. 20 Tahun 2003 Tentang Sistem Pendidikan Nasional pada Pasal 1 ayat 5 menyatakan bahwa, "Tenaga kependidikan adalah anggota masyarakat yang mengabdikan diri dan diangkat untuk menunjang penyelenggaraan pendidikan". Guru merupakan faktor yang sangat dominan dan penting dalam pendidikan formal pada umumnya karena bagi peserta didik guru sering dijadikan tokoh teladan, bahkan menjadi tokoh identifikasi dirinya. Oleh karena itu guru harus memiliki cara-cara, strategi, dan pendekatan yang digunakan dalam proses pembelajaran agar siswa lebih mudah dalam memahami untuk mencapai tujuan pembelajaran. Salah satu yang harus diketahui guru yaitu gaya belajar siswa. Gaya belajar adalah bagaimana cara siswa menyerap informasi yang diterma kemudian mengolahnya serta memanifestasikan dalam wujud nyata perilaku dalam hidupnya. Menurut DePorter\&Hernarcki (2016:110) "gaya belajar siswa adalah kombinasi dari bagaimana siswa menyerap, lalu mengatur, dan mengolah informasi".Gaya belajar merupakan salah satu komponen penting dalam proses pembelajaran yang harus diketahui oleh guru untuk kelancaran proses pembelajaran di kelas. Menurut Ula (2013)gaya belajar adalah bagaimana cara seseorang menyerap, mengatur informasi kemudian mengolahnya serta memanifestasikan dalam wujud nyata perilaku hidupnya. Berdasarkan penjelasan di atas dapat dirangkum bahwa gaya belajar merupakan bagaimana bentuk dan cara siswa dalam belajar untuk menyerap, memproses sampai mengolah informasi dalam proses pembelajaran.

Tidak semua siswa mempunyai gaya belajar yang sama. Kecenderungan siswa untuk belajar sangat beragam dan dipengaruhi oleh beberapa hal. Setiap anak memiliki gaya belajar yang berbeda-beda, tetapi mungkin ada juga yang memiliki gaya belajar yang sejenis. Kemampuan siswa untuk memahami dan menyerap pelajaran berbeda tingkatnya, ada yang cepat, sedang dan ada pula yang lambat.Menurut DePorter \& Hernarcki (2016:112) "gaya belajar siswa dapat dikelompokkan ke dalam tiga gaya belajar, yaitu (1) gaya belajar visual, (2) gaya belajar auditif, dan (3) gaya belajar kinestetik".

Siswa yang memiliki gaya belajar visual cenderung menyukai belajar dengan melibatkan indra penglihatan, siswa yang memiliki gaya belajar auditori cenderung mnyukai cara belajar dengan melibatkan indra pendengaran, sedangkan siswa yang memiliki gaya belajar kinestetik cenderung menyukai belajar dengan melibatkan fisik atau dengan bergerak, menyentuh dan bekerja. Bagaimanapun gaya belajar siswa itulah cara terbaik mereka untuk menyerap materi pelajaran dan mencapai tujuan pembelajaran dengan optimal.

Menurut Uno (2012) beberapa ada beberapa pendekatan yang bisa digunakan sehingga belajar tetap bisa dilakukan dengan memberikan hasil yang optimal. Pendekatan yang baik digunakan untuk siswa yang memiliki gaya belajar visual salah satunya adalah menggunakan beragam bentuk grafis untuk menyampaikan informasi atau materi pelajaran. Perangkat grafis itu bisa berupa film, slide, gambar ilustrasi.Pendekatan yang bisa digunakan untuk siswa yang memiliki gaya belajar auditori yaitu menggunakan tape perekam sebagai alat bantu. Alat ini digunakan untuk merekam bacaan atau ceramah pengajar di depan kelas untuk kemudian didengarkan kembali Pendekatan kedua yang bisa dilakukan adalah dengan wawancara atau terkibat dalam kelompok diskusi. Sedangkan pendekatan ketiga adalah dengan mencoba membaca informasi, kemudian diringkas dalam bentuk lisan dan direkam untuk kemudian didengarkan dan dipahami. Dan Siswa yang memiliki gaya belajar kinestetik pendekatan belajar yang mungkin bisa dilakukan adalah belajar berdasarkan atau melalu pengalaman dengan menggunakan berbagai model atau peraga, bekerja di laboratorium atau bermain sambil belajar. Cara lain yang juga bisa digunakan adalah secara tetap membuat jeda di tengah waktu belajar.

Gaya belajar siswa yang sesuai denganmetode pembelajaran guru yang tepat dalam menyampaikan materi dikelas, dapat mempengaruhi siswa untuk lebih bersemangat mengikuti pembelajaran. Gaya belajar yang kurang tepat dikhawatirkan akan mempersulit siswa dalam menerima, menyerap dan mengolah informasi yang diberikan guru sehingga akan banyak 
memakan waktu pembelajaran. Maka dari itu guru harus memperhatikan gaya belajar siswa yang berbeda-beda, apabila guru memperhatikan cara guru mengajar dan memperhatikan gaya belajar siswa maka siswa akan bersemangat, antusias dan termotivasi untuk mengikuti kegiatan pembelajaran dikelas.

Motif adalah keadaan dalam pribadi seseorang individu yang mendorong individu untuk melakukan aktivitas - aktivitas tertentu guna mencapai sesuatu tujuan.Menurut McClelland (dalam Uno 2016: 9) "motif merupakan implikasi dari hasil pertimbangan yang telah dipelajari (redintergation) dengan ditandai suatu perubahan pada situasi afektif". Motivasi dapat diartikan sebagai daya penggerak yang telah menjadi aktif (Sardiman, 2016)."Motivasi adalah kondisi fisiologis dan psikologis yang terdapat dalam diri seseorang yang mendorong untuk melakukan aktivitas tertentu guna mencapai suatu tujuan atau kebutuhan" (Djaali, 2014:101)."Motivasi merupakan suatu energi dalam diri manusia yang mendorong untuk melakukan aktivitas tertentu dengan tujuan tertentu" (Sani, 2013:49).

Menurut Uno (2016) motivasi dibedakan menjadi dua yaitu motivasi intrinsik dan motivasi ekstrinsik Yang dimaksud dengan motivasi instrinsik adalah motif-motif yang menjadi aktif atau berfungsinya tidak perlu dirangsang dari luar, karena dalam diri setiap individu sudah ada dorongan untuk melakukan sesuatu.Sedangkan Motivasi ekstrinsik adalah motif - motif yang aktif dan berfungsinya karena adanya perangsang dari luar.

Belajar adalah proses pengembangan diri dari tidak mengetahui sestuatu menjadi mengetahui sesuatu yang berlangsung seumur hidup. "Belajar adalah usaha sadar dari individu untuk memahami dan menguasai pengetahuan dan keterampilan; sikap-sikap dan nilai-nilai, guna meningkatkan kualitas tingah lakunya dalam rangka mengembangkan kepribadiannya" (Prawira, 2016:229)."Belajar adalah keseluruhan proses yang melibatkan aktivitas fisik-psikis untuk mendapatkan perubahan positif dalam semua aspek tingkah laku melalui sentuhan dengan lingkungan dan pengalaman" (Ula, 2013:17). Belajar tidak hanya tentang menuntut ilmu tetapi belajar juga berbentuk kecakapan, keterampilan, sikap, pengertian, dan penyesuaian diri siswa terhadap lingkungan

Motivasi belajar adalah keinginan untuk bertindak yang muncul dari dalam diri seorang siswa untuk menuntut ilmu dan mengikuti kegiatan pembelajaran yang diberikan oleh guru dengan baik dan sesuai dengan aturan dan norma yang berlaku disekolah maupun di masyarakat. Menurut Uno (2016:23)“motivasi belajar adalah dorongan internal dan eksternal pada siswa-siswa yang sedang belajar untuk mengadakan perubahan tingkah laku, pada umumnya dengan beberapa indikator atau unsur yang mendukung"."Motivasi belajar adalah segala sesuatu yang dapat memotivasi peserta didik atau individu untuk belajar" (Sani, 2013:49)."Motivasi belajar merupakan faktor psikis yang bersifat non-intelektual" (Sardiman, 2016:75).Jadi motivasi belajar merupakan salah satu faktor yang penting sebagai penggerak atau pendorong siswa untuk belajar.

Menurut Uno (2016:23) indikator motivasi belajar dapat diklasifikasikan sebagai berikut: "(1) adanya hasrat dan keinginan belajar; (2) adanya dorongan dan kebutuhan belajar; (3) adanya harapan dan cita-cita masa depan; (4) adanya penghargaan dalam belajar; (5) adanya kegiatan yang menarik dalam belajar; (6) adanya lingkungan belajar yang kondusif". Peran motivasi yang khas adalah dalam hal penumbuhan gairah, merasa senang dan semangat untuk belajar. Motivasi itu muncul karena seseorang membutuhkan sesuatu dari apa yang akan di pelajari. Siswa yang memiliki motivasi kuat akan mempunyai banyak energi untuk melakukan kegiatan belajar. Motivasi belajar tidak hanya tumbuh dari dalam diri siswa melainkan motivasi juga muncul berkat adanya pengerak dari orang lain guna menambah semangat belajar siswa. Motivasi belajar siswa dapat muncul karena cara mengajar guru yang menarik dan gaya belajar yang tepat sesuai dengan kondisi siswa.

Berdasarkan hasil observasi dan wawancara di SD Gugus Ubud diperoleh pada jam pelajaran berlangsung seringkali siswa keluar kelas, ada juga yang bermain saat guru menjelaskan. Hal tersebut dilakuakn siswa dengan alasan mata pelajaran membosankan, guru yang mengajar materi dirasakan monoton, gaya mengajar guru tidak menarik. Artinya siswa menilai bahwa metode mengajar guru tidak sesuai dengan tipe gaya belajar siswa. Siswa dengan tipe gaya belajar visual lebih cenderung menyukai metode pembelajaran dengan 
gambar-gambar, siswa dengan tipe gaya belajar auditori cenderung menyukai bahasa verbal yang disampaikan oleh guru, dan siswa dengan tipe gaya belajar kinestetik dengan mencoretcoret buku tulisnya.

Dengan demikian apabila metode pembelajaran sesuai dengan tipe gaya belajar siswa maka siswa dapat terpacu untuk mengikuti materi pembelajaran dengan maksimal. Metode pembelajaran yang sesuai dengan tipe gaya belajar siswa maka siswa dapat bersemangat, antusias dan termotivasi untuk belajar. Sebaliknya apabila metode pembelajaran yang kurang sesuai dengan tipe gaya belajar siswa maka berdampak pada kurangnya motivasi belajar siswa sehingga tidak tercipta pembelajaran yang optimal. Karena gaya belajar siswa berhubungan dengan motivasi belajar dari pembelajaran yang diberikan oleh guru.

Dari uraian tersebutpenelitian ini dilakukan untuk mengetahui apakah gaya belajar berkorelasi secara signifikan dengan motivasi belajar, penelitian tersebut akan dilakukan dengan judul "Korelasi Antara Gaya Belajar Dan Motivasi Belajar Siswa Kelas IV SD Gugus Ubud Kecamatan Ubud Tahun Pelajaran 2017/2018".

Agar penelitian ini dapat dilakukan lebih fokus, sempurna, dan mendalam maka penulis memandang permasalahan penelitian yang diangkat perlu dibatasi variabelnya. Karena tidak hanya gaya belajar yang menjadi faktor yang dapat berhubungan dengan motivasi belajar siswa. Oleh sebab itumaka pembatasan masalah dalam penelitian ini yaitu hanya terbatas pada korelasi gaya belajar dan motivasi belajar. Dan penelitian difokuskan pada siswa kelas IV SD Gugus Ubud Kecamatan Ubud Tahun Pelajaran 2017/2018.

\section{Metode}

Penelitian ini dilaksanakan pada siswa kelas IV SD Gugus Ubud Kecamatan Ubud. Pemilihan SD Gugus Ubud Kecamatn Ubudsebagai tempat penelitian karena keterjangkauan dan kelayakan. Keterjangkauan dalam arti tempat penelitian mudah dijangkau oleh peneliti, serta kelayakan dalam arti di SD Gugus Ubud Kecamatan Ubud belum pernah dilakukan penelitian yang sama dengan penelitian ini.

Penelitian ini pada dasarnya bertujuan untuk mengetahui hubungan antara gaya belajar dan motivasi belajar dengan tidak memanipulasi variabel bebas atau menggali fakta yang sudah terjadi sebelumnya sehingga penelitian ini tergolong penelitian expost facto yang bersifat korelasi.Menurut Dantes (2012:59) penelitian expost facto merupakan suatu pendekatan pada subyek penelitian untuk meneliti yang telah dimiliki oleh subyek penelitian secara wajar tanpa adanya usaha sengaja memberikan perlakuan untuk memunculkan variabel yang ingin diteliti. "Penelitian expost facto merupakan penelitian di mana variabel- variabel bebas telah terjadi ketika peneliti mulai dengan pengamatan variabel terikat dalam suatu penelitian"(Darmadi, 2014:260).Jadi penelitian expost facto yaitu penelitian dimana peneliti tidak dapat mengontrol variabel bebas melalui manipulasi atau randomisasi, ini menunjukkan bahwa perubahanperubahan dalam variabel bebas telah terjadi begitu adanya.Dalam penelitian ini memakai tiga variabel bebas (independent variable) dan satu variabel terikat ( dependent variable ). Variabel bebas dalam penelitian ini adalah gaya belajar $(X)$ dimana gaya belajar dikelompokkan menjadi tiga sehingga terdapat 3 variabel bebas yaitu gaya belajar visual (X1), gaya belajar auditori (X2), gaya belajar kinestetik (X3), dan variabel terikat adalah motivasi belajar (Y). Hubungan antara variabel bebas dengan variabel terikat dapat digambarkan dalam bentuk kontalasi permasalahan variabel penelitian seperti berikut.

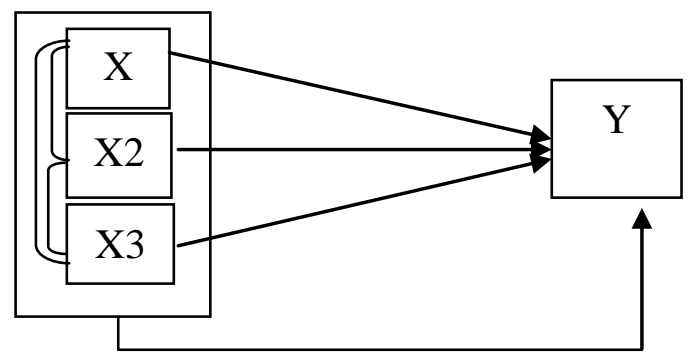


Populasi adalah keseluruhan objek atau subyek penelitian yang mempunyai kualitas dan karakteristik tertentu yang nantinya akan dikenai generalisasi kemudian ditarik simpulannya. Poupulasi dalam penelitian ini adalah semua siswa kelas IV SD Gugus Ubud Kecamatan Ubud yang terdiri dari 5 sekolah negeri dan tidak terdapat sekolah swasta. Adapun sekolah tersebut yaitu SD Negeri 1 Ubud, SD Negeri 2 Ubud, SD Negeri 3 Ubud, SD Negeri 4 Ubud, SD Negeri 5 Ubud. Jumlah siswa kelas IV SD Gugus Ubud Kecamatan Ubud tahun pelajaran 2017/2018 dengan jumlah 205 orang siswa.

Apabila jumlah populasi besar dan peneliti tidak mungkin mempelajari semua populasi yang ada maka peneliti menggunakan sampel yang diambil dari populasi.Untuk sampel yang diambil dari populasi harus betul-betul representatif (mewakili).

Sampel merupakan bagian dari jumlah populasi yang dianggap mewakili seluruh karakteristik populasi yang diambil mengunakan teknik tertentu.Penelitian ini teknik sampel yang digunakan proporsional random sampling.Teknik proporsional random sampling yaitu pengambilan sampel dengan memperhitungkan jumlah proporsi atau besar kecilnya perbandingan masing-masing kelas.

Penentuan jumlah sampel minimal digunakan tabel yang dikembangkan dari Krecjie and Morgan (dalam Agung, 2014:80). Tabel ini digunakan untuk menentukan jumlah sampel yang diambil dari populasi secara random dengan tingkat ketelitian 95\% dan taraf signifikan $5 \%$. Sesuai dengan tabel tersebut, jumlah populasi di SD Gugus Ubud Kecamatan Ubud sebanyak 205 orang, sedangkan populasi yang ada dalam tabel Krecjie and Morgan yang mendekati jumlah populasi di SD Gugus Ubud Kecamtan Ubud adalah 210 orang dengan jumlah sampel minimal adalah 136 orang.

Jika dalam penyebaran instrumen hanya 136 kuesioner yang disebar maka ada kemungkinan tidak seluruhnya kuesioner kembali dan ada juga kemungkinan kuisinoer tidak terisi secara lengkap.Untuk mengantisipasi hal tersebut maka sebaiknya dalam menyebaran kuesioner tidak sejumlah sampel minimal tetapi ditambahkan jumlah kuesioner yang sesuai jumlah sampel minimal. Untuk menghitung penambahan kuesioner agar memenuhi target atau sampel minimal yang harus diteliti menggunakan rumus Warwick dan Lininger (dalam Agung, 2014:83) sebagai berikut.

$$
\text { Js }=\frac{\mathrm{n}}{0,90 \times 0,95}
$$

Sehingga diperoleh 159 orang.Dari 159 sampel yang ditentukan hanya 150 sampel yang digunakan. Hal tersebut karena pada saat pengumpulan data ada beberapa siswa yang sudah ditetapkan menjadi sampel, saat mengisi instrumen tidak sesuai dengan ketentuan.

Untuk memperoleh data atau informasi dalam penelitian perlu dilakukan kegiatan pengumpulan data. Data yang dikumpulkan dalam penelitian ini adalah data gaya belajar dan data motivasi belajar siswa kelas IV SD Gugus Ubud Kecamtan Ubud Tahun Pelajaran 2017/2018. Dalam proses pengumpulan data tertentu diperlukan sebuah alat atau instrument pengumpulan data. Dalam penelitian ini metode pengumpulan data yang digunakan yaitu nontes.Angket adalah teknik pengumpulan data dengan cara memberikan daftar petanyaan secara tertulis kepada subjek peneliti. Angket digunakan apabila responden jumlahnya besar dan dapat membaca dengan baik.Angket juga digunakan untuk dapat mengungkapkan hal-hal yang sifatnya rahasia. Dalam penelitian ini menggunakan dua angket untuk memperoleh data yaitu angket motivasi belajar dan angket gaya belajar.

Instrumen penelitian memegang peran penting dalam penelitian kuantitatif karena kualitas data yang digunakan ditentukan oleh kualitas instrumen yang dipergunakan. Instrumen agar dapat memeberikan gambaran tentang data secara benar sesuai dengan kenyataan maka dilakukan uji validitas.Instrumen yang diuji hanya instrumen angket motivasi belajar.Sedangkan angket gaya belajar tidak dilakukan uji validitas dan reliabilitas karena menggunakan angket gaya belajar dari Bobbi DePorter dkk. Angket gaya belajar ini sudah baku dan menggunakan metotelogi yang sudah cukup teruji, biasanya survey atau angket gaya belajar ini mempunyai akurasi yang tinggi sehingga memudahkan bagi guru untuk segera mengenal gaya belajar siswa. Angket gaya belajar berjumlah 36 pernyataan. 
Validitas merupakan derajat ketepatan antara data yang terjadi pada obyek penelitian dengan data yang dapat dilaporkan oleh peneliti.Untuk mengukur validitas instrumen pertama dengan uji validitas isi yaitu menyesuaikan angket dengan indikator pada variabel.Setelah butirbutir angket sesuai dengan indikator kemudian dilakukan pertimbangan dengan ahli isi. Menurut Agung (2014:193) "validitas isi cukup diestimasi berdasarkan pertimbangan ahli isi". Sebagai ahli isi dapat ditunjuk dua orang dosen pada bidang studi yang sama.

Selanjutnya diukur menggunakan rumus korelasi pearson product moment. Kriteria pengujian yang digunakan adalah dengan membandingkan nilai $r_{x y}$ hitung dengan nilai $r_{x y}$ tabel

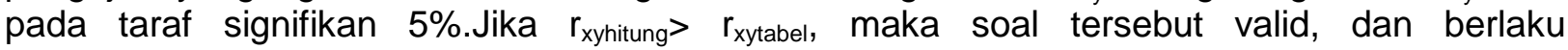
sebaliknya.Hasil hitung untuk uji validitas butir (item) pernyataan nomor satu dengan nilai $r_{\text {xyhitung }}=0,439$ dan $r_{\text {xytabel }}$ dengan taraf signifikansi $5 \%$ adalah 0,349 berarti 0,439 $>0,349$ dan pernyataan dinyatakan valid.Penghitungan ini dilakukan hingga pernyataan nomor 40, sehingga dapat diketahui bahwa hasil penghitungan terhadap 40 pernyataan adalah 30 butir butir pernyataan yang valid.

Instrumen agar dapat dipercaya dan digunakan berkali-kali hasil tes menunjukkan ketetapan maka dilakukan uji reliabilitas menggunakan teknik Alfa Cronbach.Berdasarkan hasil perhitungan terhadap 40 butir pernyataan yang dinyatakan valid diperoleh $r_{11}=0,886$. Berdasarkan kriteria derajat reliabilitas $r_{11}$ berada pada rentangan 1,00 atau $>0,80$ yang berarti pernyataan pada penelitian ini tergolong reliabel sangat tinggi

Setelah diperoleh data gaya belajar dan motivasi belajar siswa maka akan dilakukan analisis data dengan statistik deskriptif dan statistik iferensial. Statistik deskripstif digunakan untuk mendesjripsikan atau menggambarkan data.Data yang akan dideskripsikan antara lain yaitu data gaya belajar visual, data gaya belajar auditori, data gaya belajar kinestetik dan data motivasi belajar. Karena tujuannya demikian, maka akan dicari harga rata-rata, simpangan baku, nilai tengah, nilai paling sering muncul setiap variabel yang diteliti.

Statistik inferensial ini digunakan untuk menarik kesimpulan mengenai keseluruhan data dari populasi.Dalam penelitian ini statistik inferensial yang digunakan yaitu uji persyaratan kemudian uji hipotesis.Uji persyaratan digunakan untuk mengetahui apakah analisis data uji hipotesis dapat dilanjutkan atau tidak. Dalam pengujian analisis menggunakan korelasi pearson product moment dan analisis regresi linear ganda. Dalam menggunakan regresi linier ganda memerlukan beberapa asumsi atau prasyarat analisis yakni: 1) uji normalitas 2) uji linieritas dan (3) uji multikolinearitas.

Uji normalitas bertujuan untuk menguji apakah data dalam sebuah variabel terikat, variabel bebas atau keduanya memiliki distribusi normal atau tidak.Uji hipotesis menggunakan product moment dan regresi linier ganda yang baik adalah yang memiliki distribusi data normal atau yang mendekati normal.Pengujian normalitas data dalam penelitian ini dilakukan dengan menggunakan statistik Kolmogorov-Smirnov atau Sahfpiro-Wilk, dengan bantuan fasilitas SPSS 13.0 for window.

Uji linearitas dilakukan untuk mengetahui bentuk hubungan antara variabel terikat dengan masing-masing variabel bebas.Pedoman untuk melihat kelinieran adalah dengan mengkaji lajur Dev.From linierity dari modul means, sedangkan untuk melihat keberartian arah regresinya berpedoman pada lajur linierity.Statistik yang dihasilkan dari modul tersebut adalah statistik $\mathrm{F}$. Harga $F$ yang diperoleh kemudian dikonsultasikan dengan harga $F$ tabel pada taraf $\alpha=0,05$. Kriteria yang digunakan adalah: 1) uji linieritas, pada rajur Deviation From Linierity, jika $\mathrm{F}_{\text {hitung }}<$ $F_{\text {tabel }}$ dengan $p>0.05$ maka dinyatakan bahwa bentuk regresinya linier, dan sebaliknya jika $F_{\text {hitung }}>F_{\text {tabel }}$ dengan $P<0,05$ maka regresinya tidak linier, 2) uji keberartian arah regresi, pada lajur linierity, jika $\mathrm{F}$ linierity dengan $\mathrm{p}<0,05$ maka koefisien regresi yang diperoleh signifikan dan bila $p>0,05$ maka koefisien regresi yang diperoleh tidak signifikan. Untuk menguji linieritas dan keberartian koefsien regresi digunakan program SPSS 13.0for windows.

Uji multikolinearitas bertujuan untuk mengetahui hubungan yang bermakna (korelasi) antara setiap variabel bebas dalam suatu model regresi.Model regresi yang baik adalah tidak terjadi korelasi di antara variabel bebas. Jika suatu model regresi terdapat gejala multikolinier dan dipaksakan untuk digunakan, maka akan memberikan hasil prediksi yang menyimpang. Multikolinearitas dapat dilihat dari nilai tolerance atau variance inflation factor (VIF). Jika nilai 
tolerance lebih besar dari $10 \%$ atau VIF kurang dari 10, maka dapat dikatakan model telah bebas dari masalah multikolinearitas. Untuk menguji multikolinearitas digunakan program SPSS 13.0 for windows.

Untuk menguji hipotesis pertama, kedua, dan ketiga digunakan teknik analisis korelasi sederhana (korelasi product moment) dengan rumus

(Agung, 2016:125)

$$
\mathrm{r}_{\mathrm{xy}}=\frac{\mathrm{N} \Sigma \mathrm{XY}-(\Sigma \mathrm{X})(\Sigma \mathrm{Y})}{\sqrt{\left\{\mathrm{N} \sum \mathrm{X}^{2}-\left(\sum \mathrm{X}\right)^{2}\right\}\left\{\mathrm{N} \sum \mathrm{Y}^{2}-\left(\sum \mathrm{Y}\right)^{2}\right\}}}
$$

Untuk mengetahui signifikansi nilai $r$ tersebut, kemudian dikonsultasikan dengan nilai rtabel. Kaidah keputusannya adalah dengan menggunakan taraf signifikansi $5 \%$. Jika $r_{\text {hitung }}>r_{\text {tabel }}$ $(p<0,05)$ maka $\mathrm{H}_{0}$ ditolak berarti signifikan, sebaliknya jika $r_{\text {hitung }}<r_{\text {tabel }}(p>0,05)$ maka $\mathrm{H}_{0}$ diterima berarti tidak signifikan.Untuk menganalisis digunakan program SPSS 13.0 for windows.

Korelasi parsial digunakan untuk mengetahui korelasi antara satu variabel bebas dengan variabel terikat dengan mengendalikan variabel lainnya digunakan korelasi parsial jenjang kedua. Untuk menguji signifikansi nilai korelasi parsial dengan kaidah keputusan sebagai berikut.Jika $r_{\text {hitung }}>r_{\text {tabel }}(p<0,05)$, maka $\mathrm{H}_{0}$ ditolak berarti signifikan, sebaliknya jika $r_{\text {hitung }}<r_{\text {tabel }}(p>0,05)$ maka $H_{0}$ diterima berarti tidak signifikan. Untuk menganalisis digunakan program SPSS 13.0 for windows.

Untuk menguji hipotesis keempat menggunakan teknik analisis regresi linear ganda atau regresi linear tiga prediktor dan satu kriterium dengan rumus sebagai berikut.

$$
R y_{\cdot, 2,3}=\sqrt{\frac{\beta_{1} \sum x_{1} y+\beta_{2} \sum x_{2} y+\beta_{3} \sum x_{3} y}{\sum y^{2}}} \text { (Agung, 2017:110) }
$$

Untuk menguji signifikansi harga $R_{y 1,2,3}$ digunakan rumus sebagai berikut.

$$
F=\frac{R^{2}(N-m-1)}{m\left(1-R^{2}\right)} \quad(\text { Agung, 2017:110) }
$$

Kaidah keputusannya adalah Harga $F$ yang telah diperoleh kemudian dibandingkan dengan $F_{\text {tabel }}$ pada taraf signifikansi $5 \%$ dengan derajat kebebasan $\mathrm{dk}=\mathrm{m} ;(\mathrm{N}-\mathrm{m}-1)$. Jika Fhitung > Ftabel maka $\mathrm{H}_{0}$ ditolak, sebaliknya jika Fhitung < Ftabel maka $\mathrm{H}_{0}$ diterima. Untuk keperluan analisis digunakan program SPSS 13.0 for windows.

Untuk mengetahui seberapa besar sumbangan variabel $X$ terhadap $Y$ maka dihitung sumbangan efektif (SE) dengan terlebih dahulu mencari besar sumbangan relatif masingmasing prediktor terhadap prediksi, untuk analisis digunakan program SPSS 13.0 for windows.

\section{Hasil dan pembahasan}

Berdasarkan analisis data yang telah dilakukan didapatkan hasil sebagai berikut.

1) Pengujian hipotesis pertama dengan analisis korelasi product moment diperoleh diperloeh $r_{\text {hitung }}$ sebesar 0,277 lebih besar dari $r_{\text {tabel }} 5 \%=0,159$ dengan nilai dignifikansi 0,001 . Setelah dikontrol variabel gaya belajar auditori dan kinestetik dengan korelasi parsial, sehingga hubungan gaya belajar visual dan motivasi menjadi sebesar 0,214 dengan nilai signifikansi 0,009. Karena $r_{\text {hitung }}>r_{\text {tabel }}$ dan nilai signifikansi yang diperoleh lebih kecil dari taraf signifikansi yang ditetapkan $5 \%$ maka $\mathrm{H}_{0}$ ditolak dan $\mathrm{H}_{\mathrm{a}}$ diterima. Jadi dapat disimpulkan bawha terdapat korelasi yang signifikan antara gaya belajar visual dan motivasi 
belajar siswa kelas IV SD Gugus Ubud Kecamatan Ubud Tahun Pelajaran 2017/2018, dengan sumbangan efektif sebesar $4,9 \%$.

2) Pengujian hipotesis kedua dengan analisis korelasi product moment diperoleh diperloeh $r_{\text {hitung }}$ sebesar 0,556 lebih besar dari $r_{\text {tabel }} 5 \%=0,159$ dengan nilai dignifikansi 0,000 . Setelah dikontrol variabel gaya belajar visual dan kinestetik dengan korelasi parsial, sehingga hubungan gaya belajar auditori dan motivasi menjadi sebesar 0,509 dengan nilai signifikansi 0,000 . Karena $r_{\text {hitung }}>r_{\text {tabel }}$ dan nilai signifikansi yang diperoleh lebih kecil dari taraf signifikansi yang ditetapkan $5 \%$ maka $\mathrm{H}_{0}$ ditolak dan $\mathrm{H}_{a}$ diterima. Jadi dapat disimpulkan bawha terdapat korelasi yang signifikan antara gaya belajar auditori dan motivasi belajar siswa kelas IV SD Gugus Ubud Kecamatan Ubud Tahun Pelajaran $2017 / 2018$, dengan sumbangan efektif sebesar $27,4 \%$.

3) Pengujian hipotesis ketiga dengan analisis korelasi pearson product moment diperoleh diperloeh $r_{\text {hitung }}$ sebesar 0,253 lebih besar dari $r_{\text {tabel }} 5 \%=0,159$ dengan nilai dignifikansi 0,002 . Setelah dikontrol variabel gaya belajar visual dan auditoridengan korelasi parsial, sehingga hubungan gaya belajar kinestetik dan motivasi menjadi sebesar 0,168 dengan nilai signifikansi 0,042 . Karena $r_{\text {hitung }}>r_{\text {tabel }}$ dan nilai signifikansi yang diperoleh lebih kecil dari taraf signifikansi yang ditetapkan $5 \%$ maka $\mathrm{H}_{0}$ ditolak dan $\mathrm{H}_{\mathrm{a}}$ diterima. Jadi dapat disimpulkan bawha terdapat korelasi yang signifikan antara gaya belajar kinestetik dan motivasi belajar siswa kelas IV SD Gugus Ubud Kecamatan Ubud Tahun Pelajaran $2017 / 2018$, dengan sumbangan efektif sebesar 3,5\%.

4) Pengujian hipotesis keempat menggunakan analisis regresi ganda diperoleh derajat kebebasan (dk) pembilang $=3$ dan dk penyebut $=146$ untuk taraf signifikan $5 \%$ diperoleh $F_{\text {tabel }}$ sebesar 2,68 dan $F_{\text {hitung }}$ sebesar 27,186 dengan nilai signifikansi 0,000 . Dengan demikian harga $F_{\text {hitung }}>F_{\text {tabel }}$ sehingga $H_{0}$ ditolak dan $H_{a}$ diterima, hal ini berarti secara bersama-sama terdapat korelasi yang signifikan gaya belajar visual, auditori dan kinestetik dengan motivasi belajar siswa kelas IV SD Gugus Ubud Kecamatan Ubud Tahun Pelajaran $2017 / 2018$, dengan sumbangan efektif sebesar $35,8 \%$,

Dalam penelitian ini menunjukkan gaya belajar berhubungan dengan motivasi belajar. Gaya belajar auditori memberikan sumbangan efektif paling besar. Hal itu karena dalam kegiatan pembelajaran guru mengajar dengan metode yang lebih cenderung ceramah, sehingga siswa yang tipe gaya belajarnya dominan auditori akan memiliki semangat dan motivasi belajar yang lebih tinggi dibandingkan dengan siswa yang memiliki gaya belajar visual dan kinestetik. Bagaimanapun gaya belajar yang dimiliki oleh siswa, itulah cara terbaik mereka dalam menerima, menyerap, mengolah informasi yang diperoleh. (Chania,dkk, 2016:78)menyatakan bahwa "gaya belajar merupakan bentuk dan cara belajar siswa yang paling disukai yang akan berbeda antara yang satu dengan yang lain, karena setiap individu mempunyai kegemaran dan keunikan sendiri-sendiri yang tidak akan sama dengan individu lain".

Hasil penelitian ini sejalan dengan hasil penelitian yang dilakukan oleh Khusna (2013) dengan hasil penelitian yaitu berdasarkan hasil analisis data perhitungan statistik dengan rumus korelasi koefisien kontingensi di dapat nilai pada taraf signifikansi $5 \%, \Phi_{0}=0.530$ dan $\Phi \mathrm{t}$ $=0.404$ sehingga $\Phi_{0}>\Phi \mathrm{t}$ maka hipotesis yang diajukan dalam penelitian ini. Jadi ada korelasi yang signifikan antara gaya belajar dengan motivasi belajar siswa kelas IV SDN Kradinan 02 Dolopo.

Agar siswa mampu memiliki kecakapan, keterampilan, sikap, pengertian, dan penyesuaian diri siswa terhadap lingkungan tentunya tidaklah mudah. Guru harus menggunakan berbagai inovasi-inovasi dalam pembelajaran agar seluruh ranah kognitif, afektif dan psikomotor siswa dapat terbentuk. Dengan banyaknya inovasi yang dilakukan oleh guru, tentunya akan mempengaruhi gaya belajar siswa. Gaya belajar merupakan bentuk dan cara belajar siswa yang akan berbeda antara yang satu dengan yang lain, karena setiap individu mempunyai kegemaran dan keunikan sendiri-sendiri yang tidak akan sama dengan individu lain. Berdasarkan hal tersebut diperlukan strategi dari guru dalam pembelajaran untuk mengetahui gaya belajar siswa dan melaksanakan pembelajaran yang bervariasi sehingga ketiga gaya belajar ini dapat terayomi sehingga semua siswa yang memiliki gaya belajar yang berbeda-beda tersebut dapat berkembang secara optimal. 
Adanya berbagai macam inovasi yang dilakukan oleh guru membuat siswa menggunakan berbagai macam gaya belajar di sekolah, sehingga siswa tidak jenuh dalam belajar dan motivasi belajar siswa pun dapat ditingkatkan. Berdasarkan pemaparan sebelumnya dapat disimpulkan bahwa gaya belajar memiliki hubungan signifikan terhadap motivasi belajar siswa. Artinya bahwa semakin sesuai tipe gaya belajar siswa, maka semakin tinggi motivasi belajar siswa, begitu sebaliknya semakin tidak sesuai tipe gaya belajar siswa maka semakin rendah gaya belajar siswa. Sehingga apabila guru ingin motivasi siswa tinggi dalam proses pembelajaran, guru harus kreatif dan inovatif dalam mengemas pembelajaran yang diberikan kepada siswa.

\section{Simpulan dan saran}

Berdasarkan penelitian yang telah dilakukan, dapat disimpulkan bahwa

(1) erdapat korelasi yang signifikan antara gaya belajar visual dan motivasi belajar, dengan $r_{1} y$ sebesar 0,277 dan $r_{y 1.23}$ sebesar 0,214 lebih besar dari $r_{\text {tabel }} 5 \%=0,159$ serta sumbangan efektif sebesar $4,9 \%$.

(2) Terdapat korelasi yang signifikan antara gaya belajar auditori dan motivasi belajar, dengan $r_{2}$ y sebesar 0,556 dan $r_{y 2.13}$ sebesar 0,509 serta sumbangan efektif sebesar $27,4 \%$.

(3) Terdapat korelasi yang signifikan antara gaya belajar kinestetik dan motivasi belajar, dengan $\mathrm{rx}_{3} \mathrm{y}$ sebesar 0,253 dan $\mathrm{r}_{\mathrm{y} 3.12}$ sebesar 0,168 serta sumbangan efektif sebesar $3,5 \%$.

(4) Secara bersama-sama terdapat korelasi yang signifikan gaya belajar visual, auditori, kinestetik dengan motivasi belajar siswa kelas IV SD Gugus Ubud Kecamatan Ubud Tahun Pelajaran 2017/2018, dengan $F_{\text {hitung }}$ sebesar 27,186 lebih besar dari $F_{\text {tabel }}$ sebesar 2,68 serta sumbangan efektif sebesar $35,8 \%$.

Guru disarankan untuk menggunakan berbagai inovasi dalam pembelajaran sehingga siswa tidak merasa jenuh dalam mengikuti pembelajaran yang diberikan oleh guru dan motivasi siswa pun dalam belajar dapat ditingkatkan. Kepala Sekolah disarankan untuk memberikan fasilitas yang baik dalam proses pembelajaran sehingga materi yang disampaikan oleh guru ke siswa dapat berjalan dengan optimal. Peneliti lain disarankan untuk mengembangkan penelitian ini dengan menggunakan variabel-variabel yang lebih kompleks.

\section{Daftar rujukan}

Agung, Anak Agung Gede. 2014. Metodologi Penelitian Pendidikan. Malang: Media Publishing.

Agung, Anak Agung Gede. 2017. Statistik Iferensial Untuk Pendidikan. Singaraja: Fakultas IImu Pendidikan Universitas Pendidikan Ganesha.

Chania, Yen, dkk, 2016. Hubungan Gaya Belajar Dengan Hasil Belajar Siswa Pada Pembelajaran Biologi Kelas X SMAN 2 Sungai Tarab Kabupaten Tanah Datar. Sumatera Barat: IAIN Batusangkar (diakses pada tanggal 3 januari 2018).

DePoter, Bobbi, \& Hernacki, Mike. 2016 Quantum Learning.Bandung: PT Mizan Pustaka.

Djaali, 2014. Psikologi Pendidikan. Jakarta: Bumi Aksara.

Khusna, Vinani Khayatul. 2016. Korelasi Gaya Belajar Dengan Motivasi Belajar Siswa Kelas IV SDN Kardinan 02 Dolopo Madiun Tahun Pelajaran 2015/206.Ponorogo: STAIN (diakses pada tanggal 3 Januari 2018).

Prawira, Purwa Atmaja. 2016. Psikologi Pendidikan dalam Perspektif Baru.Yogyakarta: ArRuzz Media.

Sani, Ridwan Abdulah. 2013. Inovasi Pembelajaran. Jakarta: Bumi Aksara. 
Sardiman, A.M. 2016. Interaksi \&Motivasi Belajar Mengajar. Jakarta: PT. Raja Grafindo Persada

Ula, Sohimatul S. 2013. Revolusi Belajar. Yogyakarta: Ar-Ruzz Media.

Uno, Hamzah B. 2012. Orientasi Baru Dalam Psikologi Pembelajaran. Jakarta: PT. Bumi Aksara.

Uno, Hamzah B. 2016. Teori Motivasi \& Pengukurannya : Analisis Di Bidang Pendidikan. Jakarta: PT. Bumi Aksara. 